\title{
On An Improvement Of The Measurement Of Market Demand As It Pertains To Industrial Location ${ }^{\#}$
}

John W. Allen*

\section{INTRODUCTION}

Economists have long sought to explain industrial location patterns and to measure the relative importance of the many forces which shape location decisions. Unfortunately, data scarcity often presents empirical difficulties which bias and weaken the analytical results. A case in point is the measurement of the spatial distribution of market demand, a prominent variable in location research. While it is widely agreed that access to market demand is an important locational determinant, ${ }^{1}$ there exists no individual data set which specifically measures this variable in a satisfactory fashion for all industries. Thus, analysts have often relied on such readily available market proxies as personal income (Fuchs [2], Losch [6], Nourse [7]), population (Fuchs [2], Perloff [9]), retail sales (Harris [5]) and other similar items. But these are primarily measures of the spatial distribution of household purchasing power and thus measures of final demand. As such, they ignore intermediate markets which may be an important source of demand and therefore an important location force. Accordingly, market measures such as personal income ${ }^{2}$ may be poor estimators of market demand.

The purpose of this paper is to report the results of a pilot study designed to answer two basic questions: (1) Can an alternative measure of market demand which specifically accounts for both final and intermediate markets be developed from existing data? (2) Does it make any difference? Or, more specifically, how does this new market measure compare with the traditional measures in terms of its power of explaining the location of industry? Briefly, the answers are yes, there exists sufficient data to develop an alternative, and we believe superior, measure of market demand and there is substantial evidence to suggest that traditional measures tend to understate the importance of market demand as a determinant of location.

\footnotetext{
\# Many helpful suggestions from Professors R. Battalio, R. F. Gilbert, and T. R. Saving and the data processing assistance of S. Schwiff are gratefully acknowledged.

*Texas A \& M University.
} 


\section{MARKET DEMAND MEASUREMENT}

An empirical analysis of market demand as a locational determinant requires a considerable data set including: (1) the delineation of a set of geographic market areas, (2) the measurement of the location, or spread, of industry among these areas, and (3) the measurement of the relative size of demand for each industry's output in each market area. We use the nine Bureau of Census regions as our set of market areas and follow the customary procedure of using value-added as our measure of the location of industry. Our primary concern, however, is the measurement of market demand, and here we break with the tradition of using personal income.

While the use of personal income as a measure of market demand is naturally appealing from the viewpoint of data availability and convenience, it has two potential deficiencies. First, its use involves the tacit assumption that the percentage distribution of market demand across a given set of market areas is identical for every industry. Clearly this is not the case. Second, and perhaps even more important, the use of personal income implies a very narrow definition of the market, for it is primarily a measure of final markets. As such, it tends to ignore interindustry transactions and, therefore, the existence of intermediate markets which are also important in the location decision. Of course, all products are ultimately destined to final markets, but from the viewpoint of the individual producer, his "final" market is composed of all potential customers, whether they are household consumers or other producers. Thus, personal income and other measures which ignore interindustry transactions may be poor market demand estimators when interindustry transactions are substantial, as is the case in several manufacturing industries. Accordingly, measures of market size should take into account the existence of both final and intermediate markets as well as the considerable variation among industries in the distribution of output sold across these market areas. ${ }^{3}$

The objective of the remainder of this section is to develop a method for measuring the relative size of demand in each market area which gives specific weight to both intermediate and final demand transactions. The primary data source for this is the U.S. Interindustry Tables [10] which report the value of total transactions by industry and the distribution of output among the intermediate and final demand sectors. These data for 1963 are summarized in Table 1 and illustrate the previously noted substantial level of intermediate demand and the considerable variation among industries in the mix of output sold in each of these sectors. Output sold to intermediate markets ranges from a low of 26.4 percent in the apparel industry to a high of 99.8 percent in the primary metals industry and averages 67.2 percent with a standard deviation of 28.2 percent for all industries.

To begin, it is assumed that the value of total transactions (output) is a reasonable approximation of the total demand (size of the market) for each industry. ${ }^{4}$ Total domestic demand, or the size of the domestic market, for the $i^{\text {th }}$ industry $\left(\mathrm{M}_{\mathrm{i}}\right)$, is derived by simply netting out the value of exports from the value of total transactions.

Next we want to determine the spread of total demand among the $\mathrm{m}$ 
TABLE 1

Percent Distribution of Output Among the Intermediate and Final Demand Sectors by Industry: 1963

\begin{tabular}{|c|c|c|c|c|}
\hline \multirow[b]{2}{*}{ Industry } & \multirow[b]{2}{*}{$\begin{array}{c}\text { Intermediate } \\
\text { Demand Sectors }\end{array}$} & \multicolumn{2}{|c|}{ Final Demand Sectors } & \multirow[b]{2}{*}{ Total } \\
\hline & & $\begin{array}{c}\text { Personal } \\
\text { Consumption }\end{array}$ & Other & \\
\hline 20. Food \& Kind. Pdcts. & $29.6 \%$ & $69.3 \%$ & $1.1 \%$ & $100.0 \%$ \\
\hline 21. Tobacco Mfgrs. & 28.3 & 70.7 & 1.0 & 100.0 \\
\hline 22. Textile Mill Pdcts. & 89.6 & 10.0 & .4 & 100.0 \\
\hline 23. Apparel & 26.4 & 72.9 & .7 & 100.0 \\
\hline 24. Lumber \& Wood Pdcts: & 97.8 & 2.1 & .1 & 100.0 \\
\hline 25. Furniture \& Fixtures & 41.4 & 53.8 & 4.8 & 100.0 \\
\hline 26. Paper \& Allied Pdcts. & 91.5 & 7.6 & .9 & 100.0 \\
\hline 27. Printing \& Publishing & 76.7 & 19.7 & 3.6 & 100.0 \\
\hline \multicolumn{5}{|l|}{ 28. Chemicals \& Allied } \\
\hline Pdcts. & 76.6 & 18.1 & 5.3 & 100.0 \\
\hline \multicolumn{5}{|l|}{ 29. Petroleum \& Coal } \\
\hline Pdcts. & 55.9 & 39.2 & 4.9 & 100.0 \\
\hline 30. Rubber \& Plastics & 77.5 & 19.6 & 2.9 & 100.0 \\
\hline \multicolumn{5}{|l|}{ 31. Leather \& Leather } \\
\hline Pdcts. & 30.8 & 69.2 & .0 & 100.0 \\
\hline \multicolumn{5}{|l|}{ 32. Stone, Clay, Glass \& } \\
\hline Concrete Pdcts. & 95.6 & 3.8 & .6 & 100.0 \\
\hline 33. Primary Metals & 99.8 & .0 & .2 & 100.0 \\
\hline 34. Fabric. Metal Pdcts. & 95.6 & 3.8 & .6 & 100.0 \\
\hline 35. Nonelec. Machinery & 92.8 & 2.1 & 5.1 & 100.0 \\
\hline \multicolumn{5}{|l|}{ 36. Elec. Machin. \& } \\
\hline Equip. & 63.0 & 8.3 & 28.7 & 100.0 \\
\hline 37. Transp. Equipment & 52.7 & 29.4 & 17.9 & 100.0 \\
\hline 38. Instruments & 72.0 & 16.2 & 11.8 & 100.0 \\
\hline 39. Miscellaneous & 50.3 & 48.1 & 1.6 & 100.0 \\
\hline Average & 67.2 & 28.2 & 4.6 & 100.0 \\
\hline Standard Deviation & 26.0 & 26.4 & 7.2 & \\
\hline
\end{tabular}

Source: U.S. Bureau of Economic Analysis [10].

market areas. In other words, we require a measure of the size of the market demand for industry $i$ in the $r^{\text {th }}$ area $\left(M_{i}^{r}\right)$. Industry i's total market demand $\left(\mathrm{M}_{\mathrm{i}}\right)$ multiplied by each cell in the appropriate row of the interindustry transactions table allocates total demand among each of the intermediate and final demand sectors. That is, let $z_{\mathbf{j}}$ be the proportion of $\mathrm{M}_{\mathrm{i}}$ demanded by the $\mathrm{j}^{\text {th }}$ sector. Thus, total demand for $\mathrm{i}$ by the $\mathrm{j}^{\text {th }}$ sector $\left(\mathrm{M}_{\mathrm{ij}}\right)$ is:

$$
\mathrm{M}_{\mathrm{ij}}=\mathrm{z}_{\mathrm{j}} \mathrm{M}_{\mathrm{i}}
$$

This step only measures who the customers are. The next step is to measure where they are. Thus, it is necessary to estimate the distribution of each demand sector among the m market areas. Let $v_{j}^{r}$ be the percentage of the 
$j^{\text {th }}$ sector located in the $\mathrm{r}^{\text {th }}$ area. ${ }^{5}$ Then total demand for $\mathrm{i}$ by sector $\mathrm{j}$ in the $\mathrm{r}^{\text {th }}$ area $\left(\mathrm{M}_{\mathrm{ij}}^{\mathrm{r}}\right)$ is simply $\mathrm{v}_{\mathrm{j}}^{\mathrm{r}} \mathrm{M}_{\mathrm{ij}}$. Total demand for $\mathrm{i}$ by all sectors in the $\mathrm{r}^{\text {th }}$ area $\left(\mathrm{M}_{\mathrm{i}}^{\mathrm{r}}\right)$ is determined by summing over the $\mathrm{n}$ demand sectors in that area:

$$
M_{i}^{r}=\sum_{j=1}^{n} v_{j}^{r} M_{i j} \cdot{ }^{6}
$$

Given this measure of $\mathrm{M}_{\mathrm{i}}^{\mathrm{r}}$, we then have a different set of market demand measures for each industry incorporating variations in the mix of output distributed to the various intermediate and final demand sectors. Accordingly, we avoid the restrictive assumption of identical market distributions for every industry inherent with the use of market measures such as personal income.

As noted previously, to empirically measure market demand in accordance with the procedure described above involves the development of a substantial data set. To keep the data processing problem manageable, the scope and detail of the analysis was limited to the manufacturing industries at the 2-digit level of aggregation in the year $1963 .^{7,8}$

The results of the measurement procedure are presented in Table 2, along with the distribution of 1963 personal income and value-added among the nine market areas. ${ }^{9}$ To facilitate visual comparison, each variable is expressed as a percentage distribution. Here we begin to see the importance of accounting for interindustry linkages when estimating market demand, for if we did not we would then be using the distribution of personal income as our only measure and therefore assuming that the markets are spread identically for each industry. Having derived an alternative market measure we now have twenty separate estimates of the spread of market demand tailored to the peculiarities of each industry.

TABLE 2

Regional Distribution of Personal Income, Value Added and Market Demand by Industry, 1963

\begin{tabular}{lrrrrrrrrrr}
\hline & \multicolumn{8}{c}{ Region $^{\mathrm{a}}$ (Percentage distribution) } \\
\cline { 2 - 10 } \multicolumn{1}{c}{ Industry } & N.E. & M.A. & ENC & WNC & SA & ESC & WSC & Mtn & Pac \\
\hline $\begin{array}{l}\text { Personal Income } \\
\text { SIC Category }\end{array}$ & 6.34 & 21.56 & 21.15 & 7.85 & 12.44 & 4.62 & 7.76 & 3.74 & 14.54 \\
$\begin{array}{l}\text { 20. Food and Kindred Products } \\
\quad \text { Value Added }\end{array}$ & 4.17 & 19.41 & 23.99 & 11.72 & 10.49 & 5.16 & 7.33 & 2.97 & 14.73 \\
$\quad$ Market Demand & 5.80 & 20.47 & 21.47 & 9.65 & 12.03 & 4.86 & 7.86 & 3.75 & 14.11 \\
21. Tobacco Mfgrs. & & & & & & & & & \\
$\quad \quad$ Value Added & 0.17 & 7.49 & 0.00 & 0.00 & 73.98 & 18.08 & 0.25 & 0.00 & 0.02 \\
$\quad$ Market Demand & 4.76 & 17.88 & 15.78 & 5.89 & 28.19 & 8.07 & 5.88 & 2.77 & 10.79 \\
22. Textile Mill Pdcts. & & & & & & & & & \\
$\quad \quad \quad$ Value Added & 12.05 & 19.12 & 3.92 & 0.64 & 53.74 & 7.77 & 0.96 & 0.00 & 1.70 \\
$\quad$ Market Demand & 8.94 & 31.40 & 11.32 & 3.49 & 26.90 & 7.20 & 3.57 & 0.96 & 6.21 \\
\hline
\end{tabular}


TABLE 2 continued

Regional Distribution of Personal Income, Value Added and Market Demand by Industry, 1963

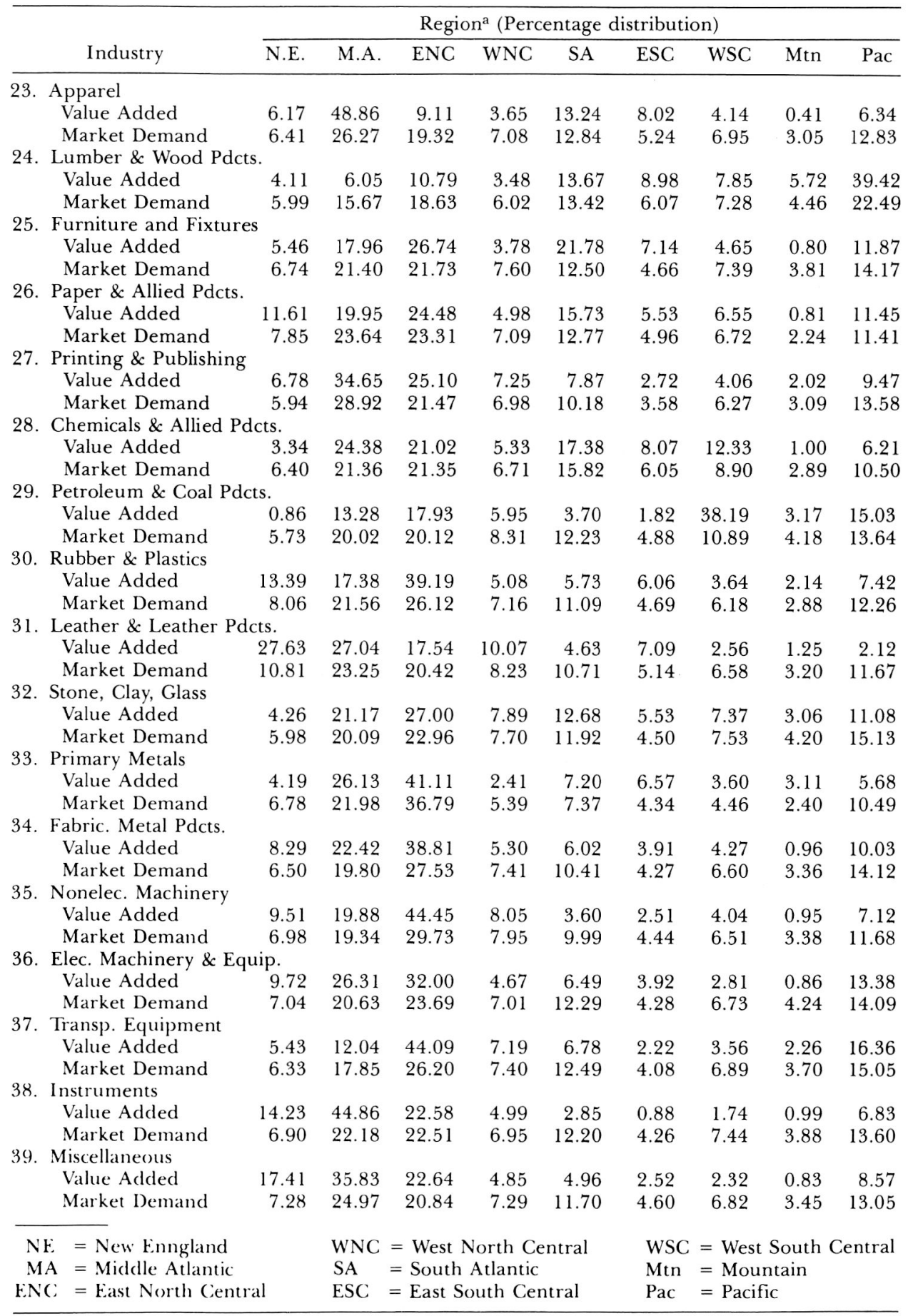




\section{NEW MARKET VS. PERSONAL INCOME MEASURE}

The extent to which the two measures of market demand differ can be seen by comparison of the personal income and market estimate rows in Table 2 and their simple correlation in Table 3. (For purposes of comparison the industries are ordered by the correlation coefficients.)

It is expected that the similarity of the two measures will vary among industries. The degree of similarity between the two measures depends upon both the extent of intermediate demand and the degree of similarity between the regional distribution of the intermediate and household demand sectors. If intermediate demand is either insignificant in size, i.e., close to zero, or distributed exactly as household demand, the two measures will be identical. However, if intermediate demand is significant and distributed differently than household demand, the market measures will be different.

In Table 3 we see that in 15 of the 21 cases the two market measures are quite similar, i.e., $r^{2}$ exceeds .90. In these industries it would appear that personal income is a reasonable proxy for market demand and only a slight improvement is realized with the new market estimate. For the remaining six cases (SIC 21, 22, 24, 33, 35, and "ALL") however, the two market estimates are considerably different reflecting the fact that the geographical distribution of intermediate demand is considerably different from that of final demand, a feature not captured by the personal income proxy. Further, it must be remembered that since many important differences are not apparent in analyses at the 2-digit level, we should expect even more dissimilarity between the two market estimates at the 3- and 4-digit levels of industrial definition. ${ }^{10}$

But more important than the similarity of the two market estimates is the relative power of each in "explaining" the location of industry. Recall that one reason for wanting an estimate of market demand is its importance as one element in accounting for the location of industry. It was alleged

TABLE 3

Correlation $\left(\mathrm{r}^{2}\right)$ Between the Distributions of Personal Income and Market Estimates by Industry

\begin{tabular}{cccc}
\hline Industry & $\mathrm{r}^{2}$ & Industry & $\mathrm{r}^{2}$ \\
\hline 21 & .419 & 27 & .935 \\
22 & .427 & 23 & .939 \\
24 & .712 & 26 & .956 \\
33 & .775 & 29 & .967 \\
$\mathrm{ALL}$ & .823 & 39 & .968 \\
35 & .848 & 36 & .976 \\
31 & .902 & 32 & .983 \\
28 & .912 & 20 & .986 \\
37 & .912 & 38 & .991 \\
34 & .917 & 25 & .998 \\
30 & .934 & &
\end{tabular}


earlier that the use of personal income would tend to understate the influence of market demand as a locational determinant, which is equivalent to saying that personal income is less powerful than that of the new market measure in explaining the location of industry. How can this be demonstrated? Since new market measures have been estimated for only one year, it is not within the scope of this paper to duplicate the previous elaborate analyses of time-series, but some notion of the relative explanatory power of the two measures can be derived from a cross-section comparison of the location of industry and markets. This comparison can be made by way of simple linear regression analysis of value-added with personal income and the new market measure as independent variables in separate regression equations. The resulting $\mathrm{R}^{2}$ 's will then indicate the explanatory power of each of the market demand measures. ${ }^{11}$

Considerable variation in the $\mathrm{R}^{2}$ 's among industries is expected, for the importance of market demand vis-a-vis other factors varies among industries. But this comparison is of secondary importance to our immediate objective. Instead, we are primarily interested in comparing the values of $\mathrm{R}^{2}$ associated with the alternative explanatory variables for a given industry. That is, since both measures are designed to capture the importance of market demand such a comparison will reveal the relative explanatory power held by each.

Our hypothesis is, therefore, that the new market estimate will yield a greater $R^{2}\left(R_{m}^{2}\right)$ than will personal income $\left(R_{y}^{2}\right)$, i.e., $R_{m}^{2}>R_{y}^{2}$, and it is in this sense that we say personal income tends to understate the explanatory power of market demand in the location equation. To the extent this difference in the $\mathrm{R}^{2}$ 's is observed, we argue that this is strong, though admittedly inferential, evidence that this new measure of market demand is preferred to the traditional measure as approximated by personal income.

The data required for the regression analysis is taken from Table 2, and the regression equations are:

$$
\begin{aligned}
& \mathrm{V}_{\mathrm{i}}^{\mathrm{r}}=\mathrm{a}_{\mathrm{y}}+\mathrm{b}_{\mathrm{y}} \mathrm{Y}^{\mathrm{r}}+\mathrm{u}_{\mathrm{y}}^{\mathrm{r}} \\
& \mathrm{V}_{\mathrm{i}}^{\mathrm{r}}=\mathrm{a}_{\mathrm{m}}+\mathrm{b}_{\mathrm{m}} \mathrm{M}_{\mathrm{i}}^{\mathrm{r}}+\mathrm{u}_{\mathrm{m}}^{\mathrm{r}}
\end{aligned}
$$

where: $\mathrm{V}_{\mathrm{i}}^{\mathrm{r}}=$ Value Added (output) by Industry $\mathrm{i}$ in market area $\mathrm{r}$;

$\mathrm{Y}^{\mathrm{r}}=$ Personal Income in market area $\mathrm{r} ;{ }^{12}$

$\mathrm{M}_{\mathrm{i}}^{\mathrm{r}}=$ New estimate of market demand for Industry $\mathrm{i}$ in market area $\mathrm{r}$;

and

$$
u_{\mathrm{y}}^{\mathrm{r}} \text { and } \mathrm{u}_{\mathrm{m}}^{\mathrm{r}}=\text { random error. }
$$

The results of the alternate models are presented in Table 4 where again they are placed in rank order of the correlation coefficient $\left(\mathrm{r}^{2}\right)$ between the two market estimates as first reported in Table 3. As expected, the absolute difference between $R_{m i}^{2}$ and $R_{y i}^{2}$ varies from industry to industry, but consider the test of the significance of the difference between the $\mathrm{R}^{2}$ 's in 
TABLE 4

Comparison of Alternate Regression Equations

\begin{tabular}{|c|c|c|c|c|c|c|c|}
\hline \multirow[b]{2}{*}{ Industry } & \multirow[b]{2}{*}{$r^{2} \nabla$} & \multicolumn{3}{|c|}{$V_{i}^{r}=a_{y}+b_{y} Y^{r}+u_{y}^{r}$} & \multicolumn{3}{|c|}{$V_{i}^{r}=a_{m}+b_{m} M_{i}^{r}+u_{m}^{r}$} \\
\hline & & $\overline{\mathrm{R}_{y}^{2}}$ & $a_{y}$ & $\overline{b_{y}}$ & $\mathrm{R}_{\mathrm{m}}^{2}$ & $\mathrm{a}_{\mathrm{m}}$ & $\overline{b_{m}}$ \\
\hline 21. Tobacco & .419 & .002 & 9.353 & .158 & $.624 \uparrow \dagger$ & -15.080 & $2.357^{*}$ \\
\hline 22. Textiles & .427 & .048 & 4.909 & .557 & $.616 \dagger+\dagger$ & -2.867 & $1.257^{*}$ \\
\hline 24. Lumber & .712 & .078 & 6.025 & .459 & $.554 \uparrow+\dagger$ & -2.793 & $1.252^{*}$ \\
\hline 33. Primary Metals & .775 & .710 & -7.458 & $1.671^{*}$ & $.964 \uparrow \dagger$ & -1.897 & $1.171^{*}$ \\
\hline All Industries & .823 & .369 & -1.585 & $1.143^{*}$ & $.690 \dagger$ & $-3.896 *$ & $1.351^{*}$ \\
\hline \multicolumn{8}{|l|}{ 35. Nonelec. } \\
\hline Machinery & .848 & .604 & -6.391 & $1.576^{*}$ & $.916+\dagger$ & -6.151 & $1.555^{*}$ \\
\hline 31. Leather & .902 & .185 & 3.680 & .668 & .478 & -.867 & 1.077 \\
\hline 28. Chemicals & .912 & .712 & -.445 & $1.031 *$ & $.904+\dagger \dagger$ & -1.767 & $1.150^{*}$ \\
\hline \multicolumn{8}{|l|}{ 37. Transp. } \\
\hline Equipment & .912 & .575 & -5.390 & $1.484^{*}$ & $.827+\dagger \dagger$ & -6.707 & $1.603^{*}$ \\
\hline 34. Fabric. Metals & .917 & .745 & -6.036 & $1.543^{*}$ & $.926+\dagger \dagger$ & -4.941 & $1.445^{*}$ \\
\hline \multicolumn{8}{|l|}{ 30. Rubber \& } \\
\hline Plastics & .934 & .541 & -2.915 & $1.263^{*}$ & .779 & -3.344 & $1.301^{*}$ \\
\hline \multicolumn{8}{|l|}{ 27. Printing \& } \\
\hline Publishing & .935 & .845 & -5.807 & $1.522 *$ & $.961 \dagger \dagger$ & -2.735 & $1.245^{*}$ \\
\hline 23. Apparel & .939 & .453 & -5.079 & 1.457 & .696 & -6.789 & $1.611^{*}$ \\
\hline 26. Paper & .956 & .831 & -.316 & $1.039 *$ & .908 & .615 & $.956^{*}$ \\
\hline \multicolumn{8}{|l|}{ 29. Petroleum \& } \\
\hline Coal Products & .967 & .086 & 5.357 & .517 & .202 & 1.247 & .887 \\
\hline 39. Miscellaneous & .968 & .631 & -4.394 & $1.395^{*}$ & .774 & -4.531 & $1.407^{*}$ \\
\hline \multicolumn{8}{|l|}{ 36. Elec. } \\
\hline Machinery & .976 & .855 & -5.568 & $1.503^{*}$ & .912 & -5.220 & $1.471^{*}$ \\
\hline \multicolumn{8}{|l|}{ 32. Stone, Clay, } \\
\hline Glass & .983 & .915 & -1.620 & $1.146^{*}$ & .937 & -1.509 & $1.136^{*}$ \\
\hline \multicolumn{8}{|l|}{ 20. Food \& Kind. } \\
\hline Products & .986 & .910 & -.169 & $1.015^{*}$ & .962 & -.916 & $1.082 *$ \\
\hline 38. Instruments & .991 & .620 & -7.778 & $1.700^{*}$ & .657 & -7.272 & $1.655^{*}$ \\
\hline \multicolumn{8}{|l|}{ 25. Furniture \& } \\
\hline Fixtures & .998 & .737 & -1.655 & $1.151 *$ & .759 & -1.746 & $1.159 *$ \\
\hline Significant at & ent. & & & & & & \\
\hline $\mathrm{R}_{\mathrm{m}}^{2}$ significant & eater $t$ & $n \mathrm{R}_{y}^{2}$ & 1 percer & & & & \\
\hline$\dagger \dagger \quad \mathrm{R}_{\mathrm{m}}^{2}$ significant & ater th & $\mathrm{n}_{y}^{2}$ & 5 percen & & & & \\
\hline$\dagger+\dagger \quad \mathrm{R}_{\mathrm{m}}^{2}$ significant & ater th & $\mathrm{n} \mathrm{R}_{y}^{2}$ & 10 perce & & & & \\
\hline$\nabla \quad$ From Table 3 & & & & & & & \\
\hline
\end{tabular}

each industry. ${ }^{13}$ The null hypothesis is $\mathrm{R}_{\mathrm{mi}}^{2}=\mathrm{R}_{\mathrm{yi}}^{2}$ and the alternate is $\mathrm{R}_{\mathrm{mi}}^{2}$ $>\mathrm{R}_{\mathrm{yi}}^{2}$. If our earlier assertions are to be supported, we should find $\mathrm{R}_{\mathrm{mi}}^{2}$ to be significantly larger than $R_{y i}^{2}$ in those industries having the lowest $r^{2}$, and indeed we do. Specifically, in each of the six cases where $r^{2}$ is less than .90 , $\mathrm{R}_{\mathrm{mi}}^{2}$ is significantly greater than $\mathrm{R}_{\mathrm{yi}}^{2}$ at the 10 percent level or less. Moreover, within the group of industries having $\mathrm{r}^{2}$ 's between .90 and .95 the same result is obtained in four of seven cases, and, in the other three industries in this group $(37,30$, and 23$)$, the confidence levels are as low as 
14, 11 and 13 percent, respectively. Note also that in the case of industry 20 , even though $\mathrm{r}^{2}$ is as high as .962 , the confidence level is still only 11 percent.

It is also significant that without exception $\mathrm{R}_{\mathrm{m}}^{2}$ is consistently greater than $R_{y}^{2}$ in each of the 21 regressions. While the previous test inquired whether the $\mathrm{R}^{2}$ 's were significantly different in the case of each individual industry, we may inquire alternatively whether the combined evidence from each of the 21 tests supports the null hypothesis that $\mathrm{R}_{\mathrm{m}}^{2}=\mathrm{R}_{\mathrm{y}}^{2}$. To do so, the probability associated with the individual industry test statistic is transformed into another which has a sampling distribution approximated by the chi-square distribution. ${ }^{14}$ Applying the normal chi-square test yields a numerical value of 65.26. Since the probability of obtaining a chi-square statistic of 65.26 or larger is less than $10^{-6}$ when the mean probability in the population is .50 , the null hypothesis is rejected. Thus, a strong presumption exists that the consistent positive deviation of $\mathrm{R}_{\mathrm{m}}^{2}$ from $\mathrm{R}_{\mathrm{y}}^{2}$ in each of the regressions is not due to chance, but rather is the result of a systematic difference in the two independent variables $\mathrm{Y}^{\mathrm{r}}$ and $\mathrm{M}_{\mathrm{i}}^{\mathrm{r}}{ }^{15}$

Consider also the beta coefficients. While the larger $\mathrm{R}^{2}$ 's obtained from the new market measure give more precision to all of the beta estimates, a different interpretation results in four specific industries $(21,22,23$, and 24). Note that in these industries the beta coefficients associated with $\mathrm{Y}^{\mathrm{r}}$ are not significantly different from zero, suggesting that market demand is not at all important in influencing the location patterns in these industries. When market demand is estimated by our new measure, however, the betas are significant at one percent and indicate that on the contrary the market is indeed a relevant location force.

We emphasize that these results were obtained at the 2-digit level, for to the extent that further industrial disaggregation results in smaller $r^{2}$ 's between the two market measures (a quite likely outcome), we should expect to get significantly different results from the two market measures with greater frequency. Moreover, further industrial disaggregation is also likely to reduce the extent of intraindustry trade and thereby diminish the intraindustry shipment "problem" in our test of explanatory powers. Since industrial location studies are often made for 3- and 4-digit industries, it is apparent that their results are likely to be influenced substantially by the manner in which the market demand variable is measured.

\section{CONCLUSIONS}

We conclude that in addition to having strong intuitive appeal there is substantial empirical evidence to prefer our new measure over traditional measures of market demand. Finally, we note that while our analysis and discussions have been within the context of industrial location, the results are relevant to any field of research where market demand is to be measured or where the degree of the localization of industry is in question. 


\section{APPENDIX}

\section{Allocation of Demand Sectors Among the Market Areas}

The derivation of the new market measure requires that each of the demand sectors be allocated among the nine market areas. To do so a variety of data sources were used. Table A-1 summarizes the unit of measure, year and publication used in the allocation procedure.

In the 1963 Interindustry Tables the economy was divided into 93

TABLE A-1

Bases for Regional Distribution of the Demand Sectors

\begin{tabular}{|c|c|c|c|c|}
\hline & Demand Sectors* & Unit of Measure & Year & Publication \\
\hline 1,2 & Agriculture & Farm cash receipts & 1963 & Stat. Abst., '64 [15] \\
\hline 3 & Forestry and fisheries & Employment & 1960 & C. of Pop., '60 [15] \\
\hline 4 & $\begin{array}{l}\text { Agriculture, forestry } \\
\text { and fishery services }\end{array}$ & Employment & 1960 & C. of Pop., '60 [15] \\
\hline 5,10 & Mining & Value added & 1963 & $\begin{array}{l}\text { C. of Min. Ind., } \\
\text { '63 [14] }\end{array}$ \\
\hline 11,12 & Construction & $\begin{array}{l}\text { Pers'l inc. by } \\
\text { source }\end{array}$ & 1963 & $\begin{array}{l}\text { Sur. of Cur. Bus., } \\
\text { August, '66 [1 } 1]\end{array}$ \\
\hline $13-64$ & Manufacturing & Value added & 1963 & $\begin{array}{l}\text { C. of Manu., '63 } \\
\text { [13] }\end{array}$ \\
\hline $65-68$ & $\begin{array}{l}\text { Transportation, communi- } \\
\text { cation, electric, gas } \\
\text { and sanitary services }\end{array}$ & $\begin{array}{l}\text { Pers'l inc. by } \\
\text { source }\end{array}$ & 1963 & $\begin{array}{l}\text { Sur. of Cur. Bus., } \\
\text { August, ' } 66[11]\end{array}$ \\
\hline 69 & Wholesale and retail & Sales & 1963 & C. of Bus., '63 [12] \\
\hline 70,71 & $\begin{array}{l}\text { Finance, insurance and } \\
\text { real estate }\end{array}$ & $\begin{array}{l}\text { Pers'l inc. by } \\
\text { source }\end{array}$ & 1963 & $\begin{array}{l}\text { Sur. of Cur. Bus., } \\
\text { August, ' } 66[11]\end{array}$ \\
\hline $72-76$ & Services & Sales & 1963 & C. of Bus., '63 [12] \\
\hline 77 & $\begin{array}{l}\text { Medical, educational } \\
\text { services, and nonprofit } \\
\text { organizations }\end{array}$ & Employment & 1960 & C. of Pop., '60 [15] \\
\hline 78,79 & Government enterprises & $\begin{array}{l}\text { Pers'l inc. by } \\
\text { source }\end{array}$ & 1963 & $\begin{array}{l}\text { Sur. of Cur. Bus., } \\
\text { August, ' } 66[11]\end{array}$ \\
\hline 81 & Office supplies & $\begin{array}{l}\text { Pers'l inc. by } \\
\text { state }\end{array}$ & 1963 & $\begin{array}{l}\text { Sur. of Cur. Bus., } \\
\text { August, ' } 66[11]\end{array}$ \\
\hline 83 & $\begin{array}{l}\text { Scrap, used and } \\
\text { secondhand goods }\end{array}$ & $\begin{array}{l}\text { Pers'l inc. by } \\
\text { state }\end{array}$ & 1963 & $\begin{array}{l}\text { Sur. of Cur. Bus., } \\
\text { August, '66 [11] }\end{array}$ \\
\hline 88 & Personal consumption & $\begin{array}{l}\text { Pers'l inc. by } \\
\text { state }\end{array}$ & 1963 & $\begin{array}{l}\text { Sur. of Cur. Bus., } \\
\text { August, ' } 66[11]\end{array}$ \\
\hline 89 & $\begin{array}{l}\text { Gross private fixed } \\
\text { capital formation }\end{array}$ & $\begin{array}{l}\text { Interindustry } \\
\text { capital flows }\end{array}$ & 1958 & $\begin{array}{l}\text { Unpublished tabula- } \\
\text { tions, Bureau of } \\
\text { Labor Statistics } \\
{[17]}\end{array}$ \\
\hline 92,93 & Government purchases & $\begin{array}{l}\text { Pers'l inc. by } \\
\text { source }\end{array}$ & 1963 & $\begin{array}{l}\text { Sur. of Cur. Bus., } \\
\text { August, '66 [11] }\end{array}$ \\
\hline
\end{tabular}


sectors (87 intermediate and 6 final demand sectors) of which only 86 are relevant for this study. Most of the relevant intermediate sectors represent combinations of 3- and 4-digit industries; only a few sectors represent entire 2-digit industries. On the other hand, published data on the regional distribution of the consuming industry are most frequently available only at the 2-digit industry level and only infrequently at the 3-digit level. Consequently, most sectors were allocated to the regions according to the regional distribution of its 2-digit "parent" industry, though wherever possible a separate allocator was used for each sector. For example, Sectors 37 and 38 are both component industries of 2-digit SIC Industry 33, primary metals. Since the data relating to the regional values-added of this industry were available only for the total 2-digit industry, both Sectors 37 and 38 were allocated to the regions by the same allocator calculated for Industry 33. In effect, when data were not available for the 3- and 4-digit industry sectors, this procedure simply combined the columns of the interindustry table to sectors that corresponded to 2-digit SIC industries.

For those sectors that are allocated on the basis of 1960 employment data (Sectors 3, 4, and 77), this was the closest year to 1963 for which data were available. Obviously, 1963 data would be preferable, though the regional shifting by these industries between 1960 and 1963 was no doubt small. Since shipments to these three industries from each manufacturing industry is small and in most cases nil, the overall effect on the regional allocation as a result of having to use 1960 data was no doubt small.

Data on the regional value of sales by Sector 4- "agricultural forestry and fishery services"-were not available. Thus, the regional distribution of the combined 1960 employment in the total agricultural, forestry, and fishery industries was used as a proxy. Once again, this sector was of such little importance to any individual industry that any distortion in the data as a result of this proxy allocator was no doubt negligible.

Several sectors were allocated to the regions on the basis of the regional distribution of personal income earned in each of these sectors, i.e., "Personal Income by Source." Note, this is not the same as "Personal Income by State," which is the regional distribution of total personal income irrespective of the source, or type of employment, from which it was earned.

Finally, it should be noted that the final demand sector, "Gross Private Fixed Capital Formation," had to be redistributed back to each of the intermediate demand sectors. This was accomplished by way of an unpublished interindustry capital flows table prepared for the 1958 interindustry study and made available from the Bureau of Labor Statistics. Such a table was unavailable for 1963. It is presumed that the 1958 to 1963 change in interindustry relations was not of such a nature to affect the conclusions of our analysis.

\section{FOOTNOTES}

${ }^{1}$ For example, Greenhut $[3,104]$ has noted that, "of all the locating forces, the market factor is probably the most unique." Lösch $[6,371]$ concluded that, "the production of most goods is rather evenly distributed in respect to their sale." Perloff $[9,394]$ has written that, "for all stages of manufacturing, taken in broad categories, closeness to markets tends to be the dominant location force." And finally, recognizing that the influence of market demand varies among industries and stages of production, Hoover [4, 122] suggests that, "we should expect a particularly high degree of coincidence among the locational patterns and the market area sys- 
tems of the later stages of distribution and manufacturing." This view is not unanimous, however. In his study of historical locational shifts, Fuchs $[2,152]$ claimed that, "to be sure, no industry determines its location without giving some consideration to markets, but for the great majority of manufacturing industries, the availability of raw materials, labor, transportation, and power are usually more important considerations."

${ }^{2}$ Since the regional distribution of personal income, population and retail sales are all highly correlated, our subsequent discussion of the deficiencies of the measures will be in terms of personal income only. The conclusions derived herein are expected to apply equally well to the other proxies.

${ }^{3}$ This is not to suggest that those who have used these proxies were unaware of their potential deficiencies. Doubtless most were not. See Nourse $[7,68]$ for example.

${ }^{4}$ For our purposes it is only necessary that we know the relative size of demand in each market, that is the percentage distribution among the market areas. Thus, whether we have over- or understated the absolute level of demand is not particularly important.

${ }^{5}$ It will be recognized that the development of a measure for $v_{j}{ }^{r}$ is important to our estimation technique. Details about this procedure are found in the appendix.

${ }^{n}$ Alternatively; this may be expressed as $\mathbf{M}_{\mathrm{n}}^{\mathrm{r}}=\sum_{\mathrm{j}}^{\mathrm{n}} \mathrm{l}_{1}^{\mathrm{r}} \mathrm{v}_{\mathrm{j}} \mathrm{M}_{\mathrm{i}}$ where $\sum_{r=1}^{m} \sum_{j=1}^{n} v_{j}^{r} \gamma_{j}=1$. Note also that $M_{i}^{r}$ in turn is a component of $\mathbf{M}_{i}$ such that $\mathbf{M}_{\mathrm{i}}=\sum_{\mathrm{r}=1}^{\mathrm{m}} \mathbf{M}_{\mathrm{i}}^{\mathrm{r}}$.

${ }^{7}$ To account for interindustry transactions, it is necessary to select a year for which the U.S. Input-Output Tables are constructed (1958, 1963 and 1967). The year 1963 was chosen because of the availability of other data and calculations made in another study [1]. Working at the 2-digit level and with relatively few market areas often weakens the analysis. In this study, however, it is expected that greater industrial detail and/or more market areas will not diminish the significance of our results, but instead will reinforce the conclusions derived herein.

${ }^{8}$ Since we are considering only domestic markets, we are implicitly ignoring the influence of foreign markets on industrial locations. Doubtless, foreign markets are important for selected firms, but the problem is thought not to be particularly important since exports averaged only 3.6 percent of total manufacturing output in 1963.

${ }^{9} \mathrm{~A}$ detailed discussion of the data processing procedure is presented in the appendix.
${ }^{10}$ See, for example, Nourse $[7,67]$ for an excellent discussion of the effects of industrial aggregation.

${ }^{11}$ Of course, a high degree of similarity between the location of production and demand, and therefore a high $\mathbf{R}^{2}$, only infers and does not "prove" causation. Moreover, in instances where two establishments are located near each other because of some interindustry linkage, their proximity is the result of both a forward and a backward linkage. The observance of proximity does not, however, reveal which linkage is dominant in the location decision, and this cannot be determined by way of regression analysis. However, we may improve our perspective on the relative importance of backward linkages vis-a-vis forward linkages on the location of manufacturing production with the aid of the interindustry transactions table which is the subject of another paper currently in preparation.

${ }^{12}$ Note that the independent variable $\mathrm{Y}^{\mathrm{r}}$ has no subscript $\mathrm{i}$ because the regional distribution of personal income is the same for all industries.

${ }^{13}$ Although it is generally not possible to make inferential statements concerning the difference in $\mathrm{R}^{2}$ 's for different regression equations, in the case of simple linear regressions with one explanatory variable the values of $\mathrm{R}^{2}$ and the squared correlation coefficient are computationally equivalent. Our inferential statements are based on the significance of the differences in the squared correlation coefficients. (See Pearson and Hartley [8] for this test of significance.)

${ }^{14}$ See Winer, B. J. [18].

${ }^{15}$ It should be noted that the regional distribution of value-added was used as a proxy for the regional distribution of the manufacturing demand sectors, $v_{j}^{r}$, (see appendix A). Thus, value-added is at times a part of both our dependent and independent variables in the regression equation, and, to the extent there are intra-industry shipments, this will tend to give an upward bias to $R_{\mathrm{m}}^{2}$.

The extent of intra-industry shipments ranges from 3.0 to 34.8 percent and averages 18.9 percent for all industries. By simple regression analysis we estimate that some 40 percent of the differences between $R_{m}^{2}$ and $R_{y}^{2}$ is explained by intra-industry trade. Thus, in some industries the observed difference between $R_{m}^{2}$ and $R_{y}^{2}$ may be the result of this bias and not an actual improvement in explanatory power. However, in view of the extremely significant chi-square statistic, we can stand considerable bias in our regression model and still retain significance in the chi-square test of the combined evidence from the 21 separate tests.

\section{REFERENCES}

1. Allen, John W., Illinois Interregional Trade, 1963: Trading Patterns of Manufacturing and Wholesale Industries, Department of Business and Economic Development: State of Illinois, Springfield, 1967.

2. Fuchs, Victor R., Changes in the Location of Manufacturing in the United States Since 1929, Yale University Press, New Haven, 1962.

3. Greenhut, Melvin L., Plant Location in Theory and Practice, The University of North Carolina Press, 1956.

4. Hoover, Edgar M., The Location of Economic Activity, McGraw-Hill, New York, 1948.

5. Harris, Chauncy D., "The Market as a Factor in the Localization of Industry in the United States," Annals of the Association of American Geographers, December, 1954, pp. 315-348.

6. Lösch, August, The Economics of Location, Woglom, William H., translator, Yale University Press, New Haven, 1962.
7. Nourse, Hugh O., Regional Economics, McGraw-Hill, New York, 1968.

8. Pearson, E. A. and Hartley, H. O., eds., Biometrika Tables for Statisticians, Volume 1, The University Press, Cambridge, 1958.

9. Perloff, Harvey S., et. al., Regions, Resources and Economic Growth, University of Nebraska Press, Lincoln, 1960.

10. U.S. Bureau of Economic Analysis, "The Input Output Structure of the U.S. Economy: 1963," Survey of Current Business, Washington, November 1969, pp. $30-35$.

11. , Survey of Current Business, Washington, August 1966.

12. U.S. Bureau of the Census, Census of Business, 1963, Washington, U.S. Government Printing Office, 1965.

13. Census of Manufacturers, 1963, Washington, U.S. Government Printing Office, 1965. 
14. Census of Mineral Industries, 1963, Washington, U.S. Government Printing Office, 1965.

15. Census of Population, 1960, Washington, U.S. Government Printing Office.

16. - Statistical Abstract of the United States, 1964, Washington, U.S. Government Printing Office, 1964 .

17. U.S. Bureau of Labor Statistics, Interindustry Capital
Flows, Washington, Bureau of Labor Statistics, 1966 (unpublished tabulations).

18. U.S. Office of Business Economics, "State Personal Income, 1948-65," Survey of Current Business, August 1966, pp. 11-18.

19. Winer, B. J., Statistical Principles in Experimental Design, 2nd ed., McGraw-Hill, New York, 1971. 